\title{
Lime mortars with ceramic wastes: characterization of components and their influence on the mechanical behaviour
}

Construction and Building Materials 73 (2014), 523-534 http://dx.doi.org/10.1016/i.conbuildmat.2014.09.108

Gina Matias $^{a_{*}}$, Paulina Faria ${ }^{b}$, Isabel Torres ${ }^{c}$

${ }^{a}$ ITeCons - Institute for Research and Technological Development in Construction Sciences, Rua Pedro Hispano, s/n, 3030-289 Coimbra, Portugal

${ }^{\mathrm{b}}$ UNIC, Department of Civil Engineering , Faculty of Sciences and Technology, Universidade Nova de Lisboa, Quinta da Torre, 2829-516 Caparica, Portugal

${ }^{c}$ Department of Civil Engineering , Faculty of Sciences and Technology, University of Coimbra, Rua Luís Reis Santos - Pólo II, 3030-788 Coimbra, Portugal

* Corresponding author:

Gina Matias

Researcher

ITeCons - Institute for Research and Technological Development in Construction Sciences, Rua Pedro Hispano, s/n, 3030-289 Coimbra, Portugal

E-mail: ginamatias@itecons.uc.pt

Phone: 00351239798937

Fax: 00351239798939 


\begin{abstract}
Considering the fundamental importance of preserving the built heritage and of ensuring the good performance achieved by incorporating ceramic particles in lime mortars in ancient times, it is important to study solutions that use materials the available today, in order to produce mortars intended to repair and replace the old ones. Solutions incorporating industrial ceramic waste might be profitable for several reasons, namely for economic, environmental and technical aspects. In this paper, seven ceramic waste products collected from ceramics factories are characterized. Their mineralogy, dimensional features and pozzolanicity were determined. Three of these products, with different particle size fractions (obtained directly from milling, dust only and fragment fractions only), were selected, incorporated into air lime mortars, and their mechanical strength was determined. In the present work, evidence of mechanical efficiency, when common sand or air lime were partially replaced by ceramic wastes, was made clear, drawing attention to the sustainability of this type of mortars, hence, encouraging further research.
\end{abstract}

\title{
Highlights:
}

- Lime mortars with ceramic dust and fragments have been often used in the past.

- Solutions for the disposal of waste from the ceramic industry are urgently needed.

- Dust fraction of industrial ceramic waste may demonstrate pozzolanic activity.

- Dust and fragments of ceramic wastes increase the mechanical strength of air lime mortars.

- Ceramic waste incorporated in mortars compositions may work as a natural pigment.

Keywords: ceramic waste; old mortar; air lime mortar; pozzolan; filler; aggregate. 


\section{Introduction}

Hydrated lime mortars with the addition of several materials have been very often used in the past. These additions, especially pozzolans, were intended to improve the behaviour of mortar, and were mainly obtained from natural sources. Products such as heat treated clays and ash have been often detected in old mortars. Heat treated clays from ceramic products, such as bricks and tiles that were milled and incorporated in lime mortar, were common ingredients in ancient times and were used when natural pozzolans were not available.

It has been observed that heat treated clays can provide hydraulic characteristics to air lime mortars. Silica $\left(\mathrm{SiO}_{2}\right)$ and alumina $\left(\mathrm{Al}_{2} \mathrm{O}_{3}\right)$, which are found in pozzolanic materials, may, when combined with $\mathrm{Ca}(\mathrm{OH})_{2}$ and water, form calcium silicates and aluminates, if certain conditions (which will be addressed later) are gathered. The final product can therefore harden in the presence of water, which does not happen when a mortar contains only air lime [1]. In the specific case of heat treated clay, the degree of pozzolanic activity depends on several factors. The type of clay and the amount of silica and alumina available to react with the $\mathrm{Ca}(\mathrm{OH})_{2}$ and fixate the calcium hydrate $(\mathrm{CaH})$ [2] are the main characteristics of interest. However, other aspects such as the degree of crystallinity, mainly conditioned by the thermal treatment conditions (heating period, temperature and type of cycles), and the specific surface area of the particles, are also crucial $[2,3]$. The temperature of the thermal treatment seems to be an aspect of critical importance. According to researchers [1,4-9] the amount of amorphous material produced is strongly influenced by the clay mineralogy, and the ideal temperature to develop reactivity also varies.

Mortars containing ceramic fragments became popular during the Roman Empire as their hydraulic properties met with the requirements for the construction of baths, water conduits, reservoirs and cisterns [10]. This mixture, known as opus testaceum and cocciopesto $[3,11]$ has been well documented by Catone and Vitruvius [12]. The knowledge of its principles spread throughout Europe, North Africa and Asia [2,6]. Nonethless, evidence has been found of prior use of these type of products as masonry elements [12-15]. In addition to their common use from empirical knowledge, mortars made with heat treated clays obtained from milled by-products were also known to be quite long-lasting and reliable. Its considerable number of advantages led to their use for many centuries. This type of mortars 
can be easily found in historic buildings and archaeological sites till this day, which is a good indicator of its longevity.

Research has been undertaken over the years to understand and explain why mortars with ceramic waste were regularly used in the past. Some researchers characterized old mortars used in historical buildings so as to understand, not only the characteristics of the ceramics used in the past, such as the temperature treatment and mineralogy of the clay, but also how the mortars were produced in terms of proportions and aggregates size distribution. Other researchers have revealed that newer ceramics might have potential as pozzolans or as aggregates when incorporated into lime and cement mortars along with being compatible with old buildings masonry on which this technique was applied in the past $[3,4,7-9,11-13,16,-21]$. Nowadays, the ceramic industry creates a significant amount of waste for disposal. Most factories reject large amounts of final products due to high quality requirements. In brick and roof tile factories, whose main raw materials are clay and silica, the paste is subjected to heat treatment at relatively high temperatures, which involves high energy costs. Final products frequently exhibit small defects like cracking and warping, and are therefore unmarketable. A small number of factories reintroduce parts of the defective materials into the production cycle and sometimes waste is sold for exterior sports floor paving. However, this does not happen very often. Therefore, it is very important to find solutions that may use larger quantities of this type of waste.

In the specific case of Portugal, in 2003 it was estimated that $37 \%$ of the waste produced by ceramics factories originated from heat treated products and its most common destination was landfill disposal [22]. According to the information collected from The European Pollutant Release and Transfer Register [23], in Portugal, manufacturers of ceramic products, including tiles, bricks, stoneware and porcelain, produced about 102,329 tonnes of non-hazardous waste in $2011,7.8 \%$ of which was not recovered. Even though this percentage may be small, it still represents 8,029 tonnes of waste whose most probable destination is landfill.

Apart from these environmental advantages, there are other benefits from using ceramic waste. When used to partially replace the constituents of mortars, ceramic particles help to reduce the consumption of natural aggregates or binder. The production of binder requires the consumption of energy and, consequently of fossil fuels. It also involves the emission of a considerable amount of $\mathrm{CO}_{2}$ and a consumption of appreciable quantities of natural resources. 
When it comes to aggregates, the massive extraction of natural sand can have disastrous environmental consequences. Therefore, the incorporation of ceramic waste into mortars may offer environmental advantages as well as economic and technical benefits, in particular when the pozzolanic reactions and filler behaviour are considered.

Previous research has shown that, while there have been some studies on mortars with ceramic waste, most of them concern cement mortars. On the other hand, publications regarding air lime mortars have not provided an in-depth description of industrial ceramics and are not up-to-date. For the mentioned reasons the time is ripe for systematizing this characterization. The research work presented in this paper is therefore looking at the industrial ceramic waste produced from common clays used to manufacture building materials (bricks and roof tiles) and ornamental ceramics (pottery), obtained locally from the central region of Portuguese Mainland.

Once all the relevant details about the clay production processes (materials used, thermal treatment and production stages) were gathered, the collected samples were milled and their physical and chemical properties were characterized. Some of the waste materials were then incorporated into air lime mortars mixtures in different proportions, partially replacing the natural sand or binder. The mechanical behaviour of the mortars was analysed aimed at providing an insight into the contribution of these wastes to the performance of mortars, when compared to common mortars without additions.

\section{Preparation and characterization of the materials}

\subsection{Industrial production characteristics}

Samples of waste composed of roof tiles, bricks and pottery were collected from ceramic industries located in the central region of Portuguese Mainland. They were used to represent the most common ceramic waste materials. Seven different products were gathered from four selected companies, along with relevant information about the current production and ceramic waste treatment procedures.

It was found that most factories do not use the waste dismissed by the quality inspection process (which sorts out items with flaws caused by production mistakes or breakage during handling). Deposits with large amounts of waste that have accumulated over time are a common sight outside these industrial facilities. The hardness of the products means that degradation is almost non-existent, which creates a long term problem of waste management. 
The information gathered from the selected factories is summarized in Table 1. The products are defined by their commercial designation given by the producer. For this reason some tiles are defined as "high quality" in comparison to regular ones. The thermal treatment mainly occurs in a tunnel and the duration presented is refers to the entire heating period. The heating temperature is the maximum temperature that is reached in that period. The period of time at maximum temperature was not given by the factories.

As a consequence of the great amount of waste available for some sub-products, and considering the similarities in their composition, for the purpose of this analysis, W4 and W5 (Table 1) are mixtures of three different types of roof tiles, defined in terms of the nature of their materials, their production process, and the quantities of waste. Their proportions are presented in Table 2 in percentage.

Regarding the production characteristics, in terms of thermal treatment, temperature values ranging from $900{ }^{\circ} \mathrm{C}$ (bricks) to $1100{ }^{\circ} \mathrm{C}$ (pottery) were recorded. A study by Pereira et al. [9] on ceramic tiles reported signs of pozzolanicity in clays heated from $600{ }^{\circ} \mathrm{C}$ to $1200{ }^{\circ} \mathrm{C}$, although it is more common to find references to optimal conditions of around $800^{\circ} \mathrm{C}$, particularly in studies where the ceramic material was heat treated $[1,24]$. All the waste products studied fitted within this interval and, for that reason, are all likely to have some degree of pozzolanicity.

\subsection{General characterization of ceramics and other components of mortar}

Generically, mortars consist of binder, aggregate (usually sand) and water. They might contain other components, sometimes substituting binder or aggregate. Prebatched mortars usually contain admixtures.

In this study hydrated air lime CL90-S powder, produced by Lusical and marketed as $\mathrm{H} 100$ was used along with regular siliceous river sand. The ceramic materials were all characterized and compared, and some were chosen as components to incorporate into the mortars.

Physical, mineralogical and mechanical tests were performed to characterize the materials. The ceramic waste was milled in preparation for use as a potential mortar component. All aggregates (river sand and ceramic waste after milling) were characterized according to their particle size distribution, particle density, water absorption and loose bulk density. Binder and waste dust, presented in Figure 1 (where different colours can be perceived) were characterized for loose bulk density and particle size distribution. 
Besides production characteristics, knowledge of other properties that could influence their usefulness as components for air lime mortars was found to be important. Given the present economic context and the overriding purpose of this investigation, it was considered that the energy consumed in the milling process would be quite relevant to the viability of this technique. Heat treated clay can act as a pozzolan in mortar produced with ceramic dust. Therefore, it was also considered important to know the particle size distribution of the ceramic dust, its specific surface area and its pozzolanicity. To determine these characteristics, the most common methods were used. In the case of larger particles, the viability was tested by determining particle size distribution and characteristics such as loose bulk density, particle density and water absorption.

\subsubsection{Energy used for milling}

The energy required to mill each waste product was measured by the Los Angeles test, according to standard EN 1097-2 [25]. The Los Angeles coefficient (LA) is used to measure the hardness of materials, i.e. how easily it disintegrates under abrasion by normalized steel spheres. Thereby, the higher the LA coefficient the more easily the material disintegrates and, consequently, the lower the milling energy consumption. Results are presented in Table 3. The test can be said to have been performed under standard conditions, as the materials met all size requirements.

The higher LA coefficient corresponds to the W5 product ("high quality white" roof tiles), followed by W1, W6 and W7, which correspond respectively to regular roof tiles, regular bricks and regular pottery. W5 is a mixture of three different products while the rest consist of single products. The materials with the highest resistance to fragmentation were W4 and W3, which correspond mainly to high quality red tile.

It was found that all ceramic wastes had LA coefficients in the interval from 29 to 39 . Hence, it is considered that the milling energy consumption and procedure is not a barrier to this type of waste utilization. As mentioned, the waste products with the higher LA coefficient - along with the lowest resistance to fragmentation - were W1, W5, W6 and W7 and therefore are the most interesting ones in terms of milling energy requirements. 


\subsubsection{Particle size distribution}

In order to prepare the ceramic waste for use as a mortar component, it was first roughly crushed down to sizes suitable for milling in a cross beater mill with a $10 \mathrm{~mm}$ sieve (RETSCH). Fragments were then introduced into the mill in order to obtain material with particle size distribution similar to that of sand commonly used in mortars.

Particle size distribution was determined using the dry sieving method, according to the standard EN 933-1 [26]. Figure 2 shows the size distribution curves of all the ceramic materials and of the river sand.

The fineness modulus of the waste, FM, was also determined and is presented in Table 4. It was found that all ceramic components had a quite similar particle size distribution. However, W5 ("high quality white" roof tile) presents a higher percentage of material with dimensions between $0.125 \mathrm{~mm}$ and $0.5 \mathrm{~mm}$. Indeed, particle size distribution analysis showed that W5 waste had a different distribution curve. Since it was produced from a commercial paste, the granular constituent material might have had a different origin when when compared to the others, which might explain this difference. I should be noted that, as mentioned, this component exhibited the lowest milling energy from LA test.

The particle size distribution obtained for the river sand is quite similar to that for most ceramic products. However, unlike river sand, ceramic waste contains $10 \%$ to $15 \%$ of material corresponding to fines that pass through a sieve \#200 (0.0625mm aperture). The fact that the whole ceramic waste after milling contained $10 \%$ to $15 \%$ of fine material may lead to relevant differences in mortars where the aggregate was partially replaced. This may lead to changes in the pore structure since there is a higher amount of fines (ceramic dust) to fill in the spaces between grain particles. These changes are analysed further in this study. In terms of classification of the fineness modulus, according to Table B.2 of the EN 12620 standard [27], it was found that components W1, W2, W3, W5, W6 and W7 are classified as MF, meaning medium sized grain. W5 can be considered as a FF, a smaller grain aggregate that fits within the indicated gap. Products W3, W4 and W6 are classified as CF, larger grained aggregates, along with the river sand, also belonging to the CF class.

In terms of the fineness modulus, except for W4, all products are likely to be classified as MF, corresponding to a medium grain size. 


\subsubsection{Particle density and water absorption}

The density of the particles after the milling of each ceramic waste product was determined, as well as the density of the river sand, following the guidelines of standard EN 1097-6 [28]. Water absorption was determined in accordance with this same standard. Table 4 shows the results of apparent particle density, $\rho_{a}$; particle density on an oven-dried basis, $\rho_{\mathrm{rd}}$; particle density on a saturated and surface-dried basis, $\rho_{\text {ssd }}$; and water absorption after immersion for 24 hours, $\mathrm{WA}_{24}$.

All of the materials presented densities of the same order of magnitude. Differences in water absorption were more evident. Water absorption of W1 and W6 was greater than $10 \%$ and $\mathrm{W} 3$ and W4 exhibited the lowest water absorption after 24 hours. It should be noted, however, that the water absorption of river sand after 24 hours immersion is almost non-existent, thus, in terms of water absorption, all the ceramic products behaved differently from the river sand. This factor can affect the behaviour of mortar. While it might make the drying of mortars exposed to high humidity conditions more difficult, which would be useful to evaluate, it could however be beneficial during the curing period, since the amount of water plays an important role in the carbonation process.

\subsubsection{Loose bulk density and voids}

Loose bulk density, $\rho_{\mathrm{bi}}$, was determined according to standard EN 1097-3 [29] . A vessel of exactly $1.03 \mathrm{dm}^{3}$ was used and specimens were dried in an oven at $70 \stackrel{\circ}{\circ}$. The obtained values are presented in Table 4. It was also necessary to determine the loose bulk density of the river sand and air lime in order to set the mortar weight proportions in correspondence with volumetric composition. The method was the same as the one used for the ceramics and the results are shown in the same table (Table 4).

Based on the particle density values and using the same standard, it was possible to determine the voids of uncompressed material, $v$. The obtained results are also presented in Table 4. This parameter may provide some indication regarding the voids available for filling with binder paste in mortar produced with these materials and the voids in lime mortar. It is expected that the percentage of voids will decrease when river sand and waste materials are combined. 
The bulk density results for the ceramic waste vary between 0.98 and $1.45 \mathrm{~g} / \mathrm{cm}^{3}$. Waste W7 had the lowest value and W4 the highest. With the lowest bulk density, W7 might be advantageous if a lighter mortar is needed. Wastes W3 and W4 results showed the loose bulk density values closest to that of river sand. In terms of voids, the range of determined values is narrow and W4 was found to exhibit the lowest value, while W7 had the highest percentage of voids, contrary to the loose bulk density results. Wastes W2 and W3 obtained values closest to the percentage of voids of river sand.

The results obtained for density, loose bulk density and water absorption showed that only W1 and W6 had water absorption that was noticeably higher than the rest. This result may affect mortar behaviour. While it might make the drying of mortars exposed to high humidity conditions more difficult, a phenomenon that might be useful to further evaluate, it could nonetheless be beneficial during the curing period. Notice should be made that W7 might be advantageous if a lighter mortar is needed, since it had the lowest value of loose bulk density.

\subsection{Characterization of fine particles}

As previously mentioned, Figure 2 shows that, after milling, ceramics have a fine fraction of $10 \%$ to $15 \%$. The fine fraction of the ceramics (all fragments less than $0.063 \mathrm{~mm}$, also known as dust) was characterized by means of several tests, in order to understand their reactive potential as pozzolans. Thus, particle size distribution and specific surface area were determined for both ceramic waste and air lime. The mineralogical composition and the pozzolanicity of the ceramic dust were also determined and simultaneous differential and thermogravimetric analysis were performed.

\subsubsection{Particle size analysis of the fine fraction}

Wet samples of ceramic waste particles finer than $0.063 \mathrm{~mm}$ and of air lime were analysed in a Malvern Mastersizer 2000 laser particle size analyser. The apparatus functions based on standard ISO 13320-1 [30] and the analysis method is performed following the Mie Theory [31]. The percentage of particles, by volume, with dimensions from $0.02 \mu \mathrm{m}$ to $2000 \mu \mathrm{m}$, was analysed. For each material, a portion of $5 \mathrm{~g}$ was tested and five measurements of particle size 
distribution were taken. The average percentage of particles was determined for each fraction. Figure 3 presents the percentage of volume depending on the sizes.

It can be seen that the ceramic dust has a very even particle size distribution. However, waste materials W2, W4 and W5 showed larger percentages of particles with size from $20 \mu \mathrm{m}$ to 45 $\mu \mathrm{m}$ than the other sizes. Concerning air lime results, most of the material showed dimensions of $2 \mu \mathrm{m}$ to $10 \mu \mathrm{m}$.

Table 5 presents the specific surface area values and particle sizes that represent $10 \%, 50 \%$ and $90 \%$ of each sample. This data was estimated with Malvern Mastersizer 2000 software, version 5.60, for each of the five measurements performed, in terms of the mean and average values and standard deviations (StD) were determined.

Materials W4, W2 and W5 had a specific surface area result of less than $1 \mathrm{~m}^{2} / \mathrm{g}$. Sample W3 had the highest value and it was one of the wastes containing finer particles, since $90 \%$ of its particles resulted in an average size of $47.6 \mu \mathrm{m}$. W7 had the finest particles of all the ceramic wastes studied $-90 \%$ of the sample had an average particle size of $44.8 \mu \mathrm{m}$. It was expected that smaller particles would correspond to larger specific surface areas. The specific surface area determined for the air lime sample is twice that of the ceramic material with the largest specific surface area. This is because $90 \%$ of the sample has an average particle size of 18.4 $\mu \mathrm{m}$.

Since specific surface area may constrain the pozzolanic activity of ceramic wastes, it may be concluded that W1, W3, W6 and W7 offer the greatest pozzolanic potential, as they had greater specific surface areas results.

\subsubsection{Mineralogical composition}

Qualitative mineralogical composition was determined for all ceramic components in the form of dust. In the specific cases of waste W4 and waste W5, samples were prepared considering the proportions indicated in Table 2. An X-Ray Diffractometer (XRD), from PaNalytical, X'PERTPRO model, with a vertical $\theta-2 \theta$ goniometer was used. The sample was previously dried at a temperature of around $40 \stackrel{\circ}{\circ}$ to $50 \stackrel{\circ}{\circ}$, until constant mass was reached. Detected elements are presented in Table 6 .

It was ascertained that only W1, W6 and W7 contained calcite and illite in their composition. However, they were not found to contain sillimanite or mullite, unlike all the other ceramic 
wastes did. All wastes contained quartz and orthoclase and, all except for W7, had hematite in their composition.

Figure 4 shows the spectrum obtained for W6, given as an example. Like the other ceramic materials, it has a diffuse peak in the 20-30 interval, in $2 \theta$, corresponding to the presence of quartz and orthoclase.

This mineralogical analysis was able to detect potentially pozzolanic materials. However, neither the amount of these composites in the whole sample, nor their crystallization conditions were known, which means that this type of analysis fell short of making it possible to declare these wastes as pozzolanic. Ceramic wastes in which limestone was detected (W1, W6 and W7) might influence pozzolanic behaviour, since it is a raw primary compound of lime which, when submitted to heat treatment, may become a reactive product. In respect to the diffuse peaks detected within the $20-30$ range, in $2 \theta$, according to some researchers $[6,8]$ this may result from the presence of amorphous material in clay which is developed during the heat treatment. This peak was found in all the ceramic wastes studied. It might indicate the existence of reactive material in the amorphous state and consequent pozzolanicity. In the specific cases of $\mathrm{W} 1, \mathrm{~W} 6$ and $\mathrm{W} 7$, the observed peak corresponds to several materials, including illite. For illite, He et al. [32] report that the optimum heating temperature is $930^{\circ} \mathrm{C}$. Among these products, the heating temperatures were close to this value, except for W7. There is therefore a good chance that the ceramic wastes studied contain significant amounts of illite in the amorphous state.According to information given by the producer, the air lime CL used, with a loose bulk density of $0.36 \mathrm{~g} / \mathrm{cm}^{3}$, has a minimum $\mathrm{Ca}(\mathrm{OH})_{2}$ content of $93 \%$. Table 7 [33] shows its chemical composition and its loss on ignition (LOI).

\subsubsection{Thermogravimetric analysis}

The finer fraction of each ceramic waste product (less than $0.063 \mathrm{~mm}$ ) was also subjected tosimultaneous thermogravimetric analysis (TGA) and differential thermal analysis (DTA), based on the procedures described in DIN 51006 [34] and DIN 51007 [35]. These tests detect possible phase changes in materials due to their weight loss. Chemical reactions triggered by heating lead to loss of volatile materials and thus lead to changes in the weight of samples. With TGA it was possible to detect weight loss at different heating stages, up to $1000^{\circ} \mathrm{C}$. DTA was 
able to detect endothermic or exothermic reactions. In this study, a default sample of alumina was used with NETZSCH STA 449C apparatus. Table 8 presents the TGA and DTA results. From the thermogravimetric analysis performed to the ceramic dust, it was possible to assay the results of this study and to justify some occurrences, based on similar studies conducted by other researchers on mortar samples, pozzolans and ceramic elements $[16,21,36]$. It is said that weight loss recorded at near $100^{\circ} \mathrm{C}$ and associated with endothermic reactions is related to the moisture present in the samples. A loss was detected around $80{ }^{\circ} \mathrm{C}$ to $90^{\circ} \mathrm{C}$, in $\mathrm{W} 1, \mathrm{~W} 2, \mathrm{~W} 5$, W6 and W7 wastes, that might correspond to this.

Weight loss registered between $550^{\circ} \mathrm{C}$ and $650^{\circ} \mathrm{C}$, with endothermic reactions, is due to transformation of the commonest materials present in clays: kaolinite and illite. The results obtained in DTA were quite expressive: all samples showed clear losses within the mentioned range. However, this loss might only be linked to the presence of illite in the case of materials W1, W6 and W7.

Between $780{ }^{\circ} \mathrm{C}$ and $860^{\circ} \mathrm{C}$ weight loss is generally associated with endothermic reactions caused by the presence of carbonates. W1, W6 and W7 contain calcite and a loss of mass on this range may correspond to $\mathrm{CO}_{2}$ release by calcite decomposition. The ranges obtained for these samples are included in this interval but are too large to allow firm conclusions. According to Moropoulou et al. [16], old ceramics analysed in their study exhibited very stable microstructures on the $850-1050{ }^{\circ} \mathrm{C}$ range. Wastes W4, W5 and W6 did not show any change in that range on any of the analysis performed. Therefore, it seems that the materials characterized in this study may have quite a similar behaviour to those used as components for mortars in the past.

\subsubsection{Pozzolanicity}

Pozzolanic reactivity is essentially conditioned by the amounts of amorphous silica and alumina available for reaction with calcium hydroxide. The methods most often used to determine a material's level of pozzolanic reactivity are the Chapelle test, Frattini test and the compressive strength test of cement paste with partial replacement using pozzolans [37]. The Chapelle test, described in the NF P 18-513 [38] standard measures the amount of $\mathrm{Ca}(\mathrm{OH})_{2}$ consumed during the reaction with the amorphous silica and alumina present in pozzolanic materials. The Frattini test, set out in EN 196-5 [39], explains how to determine the concentration of calcium hydroxide 
and calcium oxide ions, arising from the reaction of pozzolanic material with cement. When graphically represented, these concentrations should lie below the curve indicated by the standard and represented in Figure 5, so that the material can be considered pozzolanic. The cement compressive strength test (according to EN 196-1 [40]) is also used to determine the pozzolanicity of materials when $25 \%$ of cement is replaced by pozzolan, according to EN $450-1$ [41] . However, other methods are also applicable, as the one developed by Aubert et al. [42] which quantifies the reactivity of mineral additions by measuring the amounts of gypsum and lime consumed in pastes prepared with these products.

In the study performed by Pontes et al. [37], several tests were conducted aimed at finding the best method to determine the pozzolanic activity of artificial pozzolans. The researchers verified that the Frattini and Chapelle tests were the most suitable and fastest tests. They are both less expensive and time consuming than the compressive strength test, and show a good correlation at 8 days of curing.

The Frattini test was therefore chosen in this phase of our study. Samples were reduced to dust and passed through a $0.063 \mathrm{~mm}$ sieve. An aqueous solution was prepared with each of the ceramics samples and cement with a proportion of $75 \%$ cement and $25 \%$ ceramic waste dust in water at $40 \stackrel{\circ}{ } \mathrm{C}$. The calcium ion concentration was determined after 15 days. Figure 5 shows the graph indicated in the reference standard along with the obtained concentrations. The concentration results show that all ceramic waste dusts are located below the curve, which means that all the wastes have pozzolanic potential. Because results are very close it was not possible to determine different degrees of pozzolanicity with this test alone.

\subsection{Selection and supplementary characterization of ceramic wastes for mortar production}

Three of the seven studied ceramic wastes were selected for further research. Their selection took into account the results of the tests described above and their characteristics. Regarding the origin of the waste materials and their production methods, lower heating temperatures were preferred, partly because of the energy sustainability aspect, but mainly because the pozzolanic potential is likely to be higher for ceramics fired at lower temperatures [4]. Moreover, the type of product (bricks, tiles or pottery) was also considered important, to extend possibilities. In terms 
of heat treatment, W1 and W6, made from roof tiles and bricks, have more interesting results (lower temperatures); W7 is the only ceramic from a different product - pottery.

Regarding particle size distribution, W5 presents the curve furthest from the other ceramic wastes and river sand. Therefore, W5 was excluded from the options. When small particle size distribution is analysed, as determined by laser granulometry, it was found that W1, W3, W6 and W7 are the most reactive wastes due to their higher specific surface area. Those wastes also have fine particle size distribution that is more uniform.

When the energy required for milling was analysed through the LA coefficient, W1, W5, W6 and W7 were found to have a higher LA coefficient and are therefore the ceramic wastes that need lower milling energy.

Finally, regarding mineralogical composition, W1, W6 and W7 are the only wastes that were found to contain illite and calcite. For illite, specifically, the ideal activation temperature for the amorphous state is around $930 \stackrel{\circ}{\circ}$. This value is very close to the heating temperature of $\mathrm{W} 1$ and W6 and so there is a strong possibility that these ceramics contain amorphous material. Given these aspects, the three ceramic waste products considered most suitable for the purpose of this research and selected for further studies were W1, W6 and W7. These ceramics were further characterized regarding their pozzolanicity by means of the Chapelle test, in order to try to define their pozzolanicity degree more accurately. Their loose bulk density was also determined. Air lime mortars containing these materials were produced and their mechanical behaviour was studied.

\subsubsection{Chapelle test for supplementary determination of pozzolanicity}

The methodology described in the NF P 18-513 standard [38] is based on the measurement of the amount of $\mathrm{Ca}(\mathrm{OH})_{2}$ consumed during the reaction of calcium hydroxide with the silicates and aluminates present in pozzolanic materials. A solution was prepared with each one of the ceramic waste components selected for characterization, and with $\mathrm{CaO}$, and bathed for 6 hours at $90 \stackrel{\circ}{\circ}$.

Components W1, W6 and W7 presented a loss of $\mathrm{Ca}(\mathrm{OH})_{2}$ per gram of ceramic dust of 924 , 343 and 708 , respectively. The three ceramic wastes that were selected for further characterization and to produce the mortars ( $T, B$ and $P$, respectively) exhibit lower reactivity than other pozzolanic materials such as metakaolin, of several origins, and diatomites, biomass 
ashes and glass waste products [37]. In the case of commercial metakaolin, values from 920 $\mathrm{mg}$ to $1560 \mathrm{mg} \mathrm{Ca}(\mathrm{OH})_{2} / \mathrm{g}$ metakaolin may be obtained, whereas for biomass ashes and diatomite values vary between $521 \mathrm{mg}$ and $1349 \mathrm{mg} \mathrm{Ca}(\mathrm{OH})_{2} / \mathrm{g}$ pozzolan respectively. Glass waste generally has concentrations of $1173 \mathrm{mg} \mathrm{Ca}(\mathrm{OH})_{2} / \mathrm{g}$ glass dust. Waste $\mathrm{T}$ (from roof tile waste W1), had the closest value to commercial metakaolin, and so it was assumed that this was the most reactive of the ceramic waste components studied. However, material B (from brick waste W6), had the weakest pozzolanic indicators according to this test.

\subsubsection{Loose bulk density of fine and ground particle fractions}

The loose bulk density of fine particles fraction of the ceramic wastes was determined according to the guidelines of EN 1097-3 [29] using a vessel with known exact volume of $1.03 \mathrm{dm}^{3}$, and dried samples. This parameter allowed the conversion of the volumetric proportions of mortar to mass and vice versa. The material which is retained on the $0.063 \mathrm{~mm}$ sieve, considered as aggregate and therefore is less likely to react with binder, was also subjected to the same procedure. The obtained results are presented in Table 9 and can be compared with those in Table 4 that refer to the complete waste samples directly after milling.

As dust, ceramic wastes present lower bulk densities. Values for bulk densities of grain fractions and integral fractions of each of the ceramic wastes are of the same order of magnitude, with slight fluctuations.

\section{Mortar characterization}

Several mortars were produced to analyse the behaviour of air lime mortars with incorporated ceramic wastes. The ceramic milled wastes were used with three different particle size distributions: directly after milling with the granular and the finer fractions together, without any separation, and also used separately - the granular fraction (retained in the $0.063 \mathrm{~mm}$ sieve) and the fine fraction (which has passed through the previous sieve). The granular separation was a step that was therefore only necessary for some mortars. Mortars were prepared and characterized with different percentages of each of the three selected ceramic wastes.

Mortars were tested in fresh conditions for consistency, and samples were prepared and conditioned. Flexural and compressive strength was determined after 60 days of curing. This 
period of time was defined because hydrated lime mortars have a slow carbonation process and a period of 28 days was not considered enough.

\subsection{Composition of the mortars}

All the mortars were proportioned with a volumetric binder: aggregate ratio of 1:3. Three distinct groups of air lime mortars were prepared: a first group of mortars using the entire fractions of ceramic material directly obtained from milling (unseparated grain and dust fractions), considering the total of the ceramic waste and river sand as the aggregate; a second group of mortars only containing granular ceramic particles (larger than $0.063 \mathrm{~mm}$ ), where the aggregate is the total volume of ceramic waste and river sand; a third group of mortars using only fine (dust) ceramic particles (particles finer than $0.063 \mathrm{~mm}$ ), where the binder is the total volume of lime and ceramic waste. As mentioned earlier, in the first two groups, ceramic waste was introduced as a partial substitution of the aggregate; in mortars containing only ceramic dust, it was introduced as a partial substitution of the binder. A control (reference) air lime mortar containing only air lime and river sand, also of a 1:3 volumetric composition, was prepared in order to assess the influence of the ceramic wastes. In the first two groups ceramic waste replaced $20 \%$ and $40 \%$ of river sand, in terms of volume, and in the third group the ceramic waste dust replaced $10 \%$ and $20 \%$ of air lime, in terms of volume. A total of 19 different combinations were prepared. Table 10 presents the dosages of the materials used, as well as both the volumetric and weight proportions of each sample.

For easier comprehension, mortars with brick waste W6 are denoted by the letter "B", mortars with roof tile waste W1 by "T" and mortars with decorative pottery waste W7 by "P". Mortars with the lowest substitution percentages ( $20 \%$ for the whole ceramic product and $10 \%$ for the dust) are represented by "L" and mortars with higher substitution percentages $(40 \%$ for whole ceramic product and $20 \%$ for dust) by " $\mathrm{H}$ ". Mortars that only contained the granular ceramic fraction are labelled "G" and those that only contained the dust are labelled "D".

Considering that, in the case where the unseparated ceramic waste was used (group 1), about $10 \%$ in mass corresponds to particles finer than $0.063 \mathrm{~mm}$ (Figure 2), the fines/grain ratio (in terms of volume) was determined and is presented in the last column in Table 10. The fines consist of the lime and the ceramic waste dust fraction; the grains fraction consists of the river sand and the granular fraction of the ceramic waste. 
Because the first group of mortars contained milled ceramic waste without fraction separation as a partial replacement of the river sand, those mortars contain a higher amount of fine particles than granular ones, as shown in Table 10.

\subsection{Mixing procedure, characterization of fresh mortar, sample preparation and curing}

All the dried constituents were weighed and placed in the mechanical mixer bowl. All mortars were prepared with a water content that allowed achieving $150 \pm 10 \mathrm{~mm}$ consistency measured by the flow table method, based on requirements given in EN 1015-3 [43]. The amount of water added to each sample was recorded and the water/fine particles ratio $(\mathrm{m} / \mathrm{m})$ was determined. The weight of the fine particles is the weight of the air lime plus the ceramic waste dust fraction. Prismatic specimens were prepared in metal moulds measuring $40 \mathrm{~mm} \times 40 \mathrm{~mm} \times 160 \mathrm{~mm}$ and were compacted with a jolting apparatus, based on EN 196-1 [40] requirements. In the first five days, the specimens were exposed to constant conditions of $20 \pm 2 \stackrel{\circ}{\circ}$ and $95 \pm 5 \%$ relative humidity $(\mathrm{RH})$ and, during the rest of the curing period (until testing), were maintained at the same temperature but at $65 \pm 5 \% \mathrm{RH}$. Specimens containing ceramic wastes presented a light pink coloration, as can be observed, for some examples, in Figure 6.

Figure 7 presents all the flow values and water/fine particles ratios obtained.

It was observed that the relation between consistency and water/fine particles ratio depends on the group of mortars. The relation was inversely proportional for mortars with the unseparated waste samples partially substituting the river sand and proportional for mortars with only the dust fraction partially substituting the lime. It is thus considered that the dust fraction has a great influence on fresh mortar behaviour because of the significant water absorption during preparation. It is expected that rheological studies and the possible inclusion of admixtures may help to optimize these mortars in the near future.

\subsection{Mechanical strength}

Mechanical strength was determined after 60 days of curing. Flexural and compressive strength tests were performed according to EN 1015-11 [44] recommendations. Prismatic specimens were subjected to flexural strength tests and one of the resulting halves was then used to determine compressive strength. Tests were performed with an Instron 5884 universal test equipment with a load cell of $30 \mathrm{kN}$. The results for the flexural and compressive strength tests 
for all the mortars are presented in Figure 8. In Figure 9 the test device used for flexural strength may be observed.

It can be seen that almost all of the mortars with ceramic waste have a higher compressive strength result than that of the reference mortar, which is particularly significant for mortars from group one, where the river sand was partially replaced by ceramic wastes obtained directly from milling, without granular separation. Almost all of the mortars in this group also showed an increase in flexural strength, although not as significant. Mortars from group two, where the river sand was partially replaced by the granular fraction of ceramic waste, also have higher compressive strength results, although the flexural strength generally decreased (slightly in some mortars). Mortars from group three, where the finer fraction of ceramic waste partially replaced the air lime, also achieved an increase in compressive strength, and mortars with wastes from tiles even presented a slight increase in flexural strength.

It was ascertained that all mortars had flexural strength higher than $0.1 \mathrm{~N} / \mathrm{mm}^{2}$ and lower than $0.3 \mathrm{~N} / \mathrm{mm}^{2}$. Results for this parameter were quite regular for $1: 3$ volumetric composition mortars. In fact a higher percentage of directly milled ceramic waste mortars $(\mathrm{H})$ substituting river sand are generally distinguished by their higher values, when compared to similar mortars with lower substitution percentages $(L)$.

Differences between mortar groups were more evident when it came to compressive strength. All mortars with higher substitution percentages $(\mathrm{H})$ had higher compressive strength than their equivalents with lower substitution percentages (L). As for flexural strength, mortars with $40 \%$ of directly milled ceramic waste as aggregate (unseparated granular and dust fractions) clearly stand apart from the others. Analysis of mortars with granular and dust fractions incorporated separately showed that granular ceramic mortars had higher values than those that contained only ceramic dust. However, it should be noted that the latter contained less lime since the ceramic dust replaced the binder, not the aggregate.

It was observed that the greater values obtained for mortars with higher substitution percentages (even among mortars that only contained ceramic dust, which present lower global values) may be related not only to changes in the pore structure of the mortars (due to a higher degree of pore filling and consequently greater compactness) but also to the reactions that occur between the ceramic dust and the air lime. In mortars that only contained ceramic dust, 
the lime content was smaller than in the other groups (as shown in Table 10) but the reduction in lime consumption was direct.

Furthermore, mortars that contained only ceramic granular fraction did not suffer a significant strength reduction when compared to similar directly milled ceramic mortars, and they had better values than that of the reference mortar. This might be related to two factors: on one hand angular surfaces of the ceramic particles may lead to a better cohesion between the mortar materials and, on the other hand, some pozzolanic reaction might occur between the lime and the surface of the ceramic particles, as has been suggested by other researchers [2]. Also the water absorption of the ceramics may play an important role by delaying moisture evaporation during curing.

According to Veiga et al. [4], who established some indicative requirements for replacing mortar in old buildings, an acceptable range has been established from $0.2 \mathrm{~N} / \mathrm{mm}^{2}$ to $0.8 \mathrm{~N} / \mathrm{mm}^{2}$ for flexural strength and $0.4 \mathrm{~N} / \mathrm{mm}^{2}$ to $3.0 \mathrm{~N} / \mathrm{mm}^{2}$ for compressive strength at 90 days of age. From the results obtained at 60 days of age, all directly milled ceramic waste mortars with higher substitution percentages indicate that those requirements for flexural strength will be met. Mortars that only contained granular ceramic particles and had higher substitution percentages were very close to the defined lower limit, even at 60 days of age. This conclusion is also valid for compressive strength results. However, in this case, mortars with 1:3 volumetric composition and lower aggregate replacement percentages (20\%) were also very close to the indicated lower limit, even at 60 days. Therefore, considering the reference acceptable range [45], it might be said that mortar with composition 1:3 (binder:aggregate), with aggregate replacement percentages of $20-40 \%$, are mechanically adequate and can be regarded as efficient mortars for use in the conservation of old buildings.

When compared with previous studies, in most cases, the values obtained for flexural strength are well adjusted to the ones achieved by other researchers $[5,24,46-48]$ which correspond to a range of $0.1-0.5 \mathrm{~N} / \mathrm{mm}^{2}$. When it comes to the most common values presented for old mortars $[46,48,49]$, in terms of flexural strength, mortars with ceramic waste and with higher replacement percentage are the only which fit within the range of 0.5 to $1.2 \mathrm{~N} / \mathrm{mm}^{2}$ indicated for old air lime mortars and air lime mortars with artificial pozzolans and ceramic materials. In what concerns to compressive strength, previous studies about air lime mortars with clays submitted to thermal treatment presented results, after 60 days of curing, from 0.3 to $2.2 \mathrm{~N} / \mathrm{mm}^{2}$ 
$[24,46,47,50]$. In this study all mortars, with the exception of most of the mortars that contained ceramic fine particles (with results very close to the lower limit), present values which fall within the indicated range.

Concerning studies about air lime mortars with thermally treated clays incorporated as aggregates (coarser fractions) [5,47], at 60 days, values from 0.23 to $1.04 \mathrm{~N} / \mathrm{mm}^{2}$ were given. Except for mortars with higher percentages of waste, which exceed the upper limit, all other mortars presented results between the indicated range.

\section{Conclusions}

The present paper was intended to collect and characterize ceramic wastes from industries in the central region of the Portuguese Mainland, in what concerns to production processes and mechanical and chemical properties. These waste materials were incorporated in air lime mortars as aggregates or binder and their influence in the mechanical behaviour of mortars was analysed.

The characterization of the ceramic waste dust of products collected from the ceramics factories, heat treated at temperatures from $900{ }^{\circ} \mathrm{C}$ to $1100{ }^{\circ} \mathrm{C}$, revealed some signs of possible pozzolanicity:

- Waste materials denoted as W1, W3, W6 and W7 had significantly high specific surfaces that may potentiate pozzolanic reactivity.

- In terms of mineralogical identification, silica and alumina compounds were detected (though the amount of these materials in the amorphous state was not determined). The presence of limestone was also detected in W1, W6 and W7 wastes, derived from roof tiles, bricks and pottery, which may benefit the pozzolanicity of the materials.

- In regards to DTA and TGA, reactions were observed for all ceramics at temperatures associated with the presence of illite, which might be present in significant amounts.

- With specific reference to pozzolanicity tests, the Frattini test indicated all materials as being pozzolanic, while the Chapelle test performed on W1, W6 and W7 wastes allowed the definition of pozzolanicity levels and revealed that $\mathrm{W} 1$ had the closest results to commercial metakaolin (a known reactive pozzolan). 
- The mechanical strength of mortars prepared with W1, W6 and W7 wastes was higher than that of the reference mortar without wastes, regardless of the substitution percentage, particle size distribution and type of ceramic waste.

- Even when part of the river sand was replaced only by the granular particles of ceramics, the mortar mechanical strength increased, which might indicate mechanisms that may need further research, namely by microstructural analysis.

- Mortars that contained unseparated milled ceramic wastes (both dust and granular particles) partially substituting river sand had higher mechanical strength, especially mortars with higher substitution percentages, and did not vary substantially with the type of ceramic.

- The ceramic wastes can be simply milled with low energy consumption and the direct use of the entire fractions of milled ceramic wastes eliminates the need to separate the particles further.

- The use of reddish ceramic wastes as air lime mortar components can pigment the mortars, which can be particularly interesting for conservation and rehabilitation purposes and eventually spare the need of aesthetic painting systems.

Therefore, in particular, the replacement of common sand with simply milled particles of ceramic waste seems to be a promising solution.

However, further studies should be conducted to characterize other aspects, not only with respect to the mechanical behaviour of the mortar, but also in terms of its performance in the presence of water.

\section{Acknowledgments}

The authors would like to thank the FCT- Fundação para a Ciência e Tecnologia for its support through the project "EXPL/ECM-COM/0928/2012 - Incorporation of ceramic residues in repair mortars". This work has also been framed under the Initiative Energy for Sustainability of the University of Coimbra and supported by the Energy and Mobility for Sustainable Regions EMSURE - Project (CENTRO-07-0224-FEDER-002004). 


\section{References}

[1] Faria-Rodrigues P. Resistance to salts of lime and pozzolan mortars. In: C.Groot E., editor. International RILEM Workshop on Repair Mortars for Historic Masonry: RILEM Publications; 2009. p. 99-110.

[2] Böke H, Akkurt S, İpekoğlu B, Uğurlu E. Characteristics of brick used as aggregate in historic brick-lime mortars and plasters. Cement and Concrete Research. 2006;36:111522.

[3] Moropoulou A, Bakolas A, Aggelakopoulou E. Evaluation of pozzolanic activity of natural and artificial pozzolans by thermal analysis. Thermochimica Acta. 2004;420:135-40.

[4] Teutonico JM, McCaig I, Burns C, Ashurst J. The Smeaton Project - Factors affecting the properties of lime based mortars. Bull Assoc Preservat Technol 1994;25:32-49.

[5] Faria-Rodrigues P, Henriques F. Current Mortars in Conservation: An Overview. Restoration of Buildings and Monuments. 2004;10:609-22.

[6] O'Farrell M, Sabir BB, Wild S. Strength and chemical resistance of mortars containing brick manufacturing clays subjected to different treatments. Cement and Concrete Composites. 2006;28:790-9.

[7] Lavat AE, Trezza MA, Poggi M. Characterization of ceramic roof tile wastes as pozzolanic admixture. Waste Management. 2009;29:1666-74.

[8] Budak M, Akkurt S, Böke H. Evaluation of heat treated clay for potential use in intervention mortars. Applied Clay Science. 2010;49:414-9.

[9] Pereira-de-Oliveira LA, Castro-Gomes JP, Santos PMS. The potential pozzolanic activity of glass and red-clay ceramic waste as cement mortars components. Construction and Building Materials. 2012;31:197-203.

[10] Santos-Silva A, Paiva M, Ricardo J, Salta M, Monteiro AM, Candeias AE. Characterisation of roman mortars from the archaeological site of Troia (Portugal). Materials Science Forum. 2006;1643:514-6.

[11] Bakolas A, Moropoulou A, Zendri E. Characterization of structural byzantine mortars by thermogravimetric analysis. Thermochimica Acta. 1998; 321:151-60.

[12] Baronio G, Binda L, Lombardini N. The role of brick pebbles and dust in conglomerates based on hydrated lime and crushed bricks. Construction and Building Materials. 1997;11:33-40.

[13] Moropoulou A, Bakolas A, Anagnostopoulou S. Composite materials in ancient structures. Cement and Concrete Composites. 2005; 27:295-300, 2005.

[14] Ioannou M, Philokyprou I, Theodoridou M. New evidence of early use of artificial pozzolanic material in mortars, Journal of Archaeological Science. 2013;40;3263-69. 
[15] Gillot C. The use of pozzolanic materials in Maya mortars: New evidence from Río Bec (Campeche, Mexico). Journal of Archaeological Science. 2014;47:1-9.

[16] Moropoulou A, Bakolas A, Bisbikou K. Thermal analysis as a method of characterizing ancient ceramic technologies. Thermochimica Acta. 1995;2570:743-53.

[17] Baronio G, Binda L. Study of the pozzolanicity of some bricks and clays. Construction and Building Materials. 1997;11:41-6.

[18] Velosa A, Veiga, M R. Use of brick dust and pozzolans in lime mortars for conservation purposes. XXX IAHS World Congress on Housing Proceedings. Coimbra, Portugal, 2002.

[19] Santos Silva A, Ricardo JM, Salta M, Adriano P, Mirão J, Candeias AE, Macias A. Characterization of Roman mortars from the historical town of Mertola. Heritage Weathering and Conservation. 2006;1:85-90.

[20] Toledo Filho RD, Gonçalves JP, Americano BB, Fairbairn EMR. Potential for use of crushed waste calcined-clay brick as a supplementary cementitious material in Brazil. Cement and Concrete Research. 2007;37:1357-65.

[21] Silva J, Brito J, Veiga R. Incorporation of fine ceramics in mortars. Construction and Building Materials. 2009;23:556-64.

[22] Andrade I. Production of residues in ceramics industry - Central Region 2003 (in portuguese), Central Region, Portugal: CCDRC; 2004.

[23] E-PRTR. The European Pollutant Release and Transfer Register: http://prtr.ec.europa.eu/IndustialActivity.aspx. European Environment Agency (EEA), Copenhagen, Denmark. Last accessed in 08-11-2013.

[24] Charola E, Faria-Rodrigues P, McGhie A, Henriques F. Pozzolanic components in Lime Mortars: Correlating Behaviour Composition and Microstructure. Restoration of Buildings and Monuments. 2005;11(2):111-18.

[25] CEN. EN 1097-2:2010 - Tests for mechanical and physical properties of aggregates - Part 2: Methods for the determination of resistance to fragmentation. Brussels, Belgium: CEN; 2010.

[26] CEN. EN 933-1:2012 - Tests for geometrical properties of aggregates. Part 1: Determination of particle size distribution - Sieving method. Brussels, Belgium: CEN; 2012.

[27] CEN. EN 12620:2013 - Aggregates for concrete. Brussels, Belgium: CEN; 2013.

[28] CEN. EN 1097-6:2013 - Tests for mechanical and physical properties of aggregates. Part 6: Determination of particle density and water absorption. Brussels, Belgium: CEN; 2013.

[29] CEN. EN 1097-3:1998 - Tests for mechanical and physical properties of aggregates - Part 3: Determination of loose bulk density and voids. Brussels, Belgium: CEN; 1998.

[30] ISO. ISO 13320-1:2009 - Particle size analysis - Laser diffraction methods - Part 1: General principles. Geneva, Switzerland: ISO; 2009. 
[31] Mishchenko M, Travis L, Lacis A. Scattering, Absorption, and Emission of Light by Small Particles. Cambridge, United Kingdom: Cambridge University Press, 2002.

[32] He C, Osbaeck B, E Makovicky E. Pozzolanic reactions of six principal clay minerals Activation reactivity assessments and thecnological effects. Cement and Concrete Research. 1995;25:1691-702.

[33] Gameiro A, Santos Silva A, Faria P, Grilo J, Branco T, Veiga R, Velosa A, 2014. Physical and chemical assessment of lime-metakaolin mortars: Influence of binder:aggregate ratio. Cement and Concrete Composites. 2014;54:264-71.

[34] NABau. DIN 51006 - Thermal analysis (TA) - Thermogravimetry (TG) - Principles. Germany: NABau; 2005.

[35] NABau. DIN 51007 - General principles of differential thermal analysis. Beuth, Germany: NABau; 1994.

[36] Corinaldesi V. Environmentally-friendly bedding mortars for repair of historical buildings. Construction and Building Materials. 2012;35:778-84.

[37] Pontes J, Santos-Silva A, Faria P. Evaluation of pozzolanic reactivity of artificial pozzolans. Materials Science Forum. 2013;433:730-32.

[38] AFNOR. NF P 18-513 - Metakaolin, addition pouzzolanique pour bétons. Définitions, spécifications, critères de conformité. France: AFNOR; 2010.

[39] CEN. EN 196-5:2011 - Methods of testing cement. Part 5: Pozzolanicity test for pozzolanic cement. Brussels, Belgium: CEN; 2011.

[40] CEN. EN 196-1:2005 - Methods of testing cement - Part 1: Determination of strength. Brussels, Belgium: CEN; 2005.

[41] CEN. EN 450-1:2012 - Fly ash for concrete - Part 1: Definition, specifications and conformity criteria. Brussels, Belgium: CEN; 2012.

[42] Aubert J E, Segui P, Husson B, Measson M. A method developed to quantify lime and gypsum consumed by mineral additions. Cement \& Concrete Composites. 2012;34:874-80.

[43] CEN. EN 1015-3:1999 - Methods of test for mortar for masonry - Part 3: Determination of consistence of fresh mortar (by flow table). Brussels, Belgium: CEN; 1999.

[44] CEN. EN 1015-11:2006 - Methods of test for mortar for masonary - Part 11: Determination of flexural and compressive strength of hardened mortar. Brussels, Belgium: CEN; 2006.

[45] Veiga M R, Fragata A, Velosa A, Magalhães A C, Margalha G. Lime-Based Mortars: Viability for Use as Substitution Renders in Historical Buildings. International Journal of Architectural Heritage. 2010;4:177-95.

[46] Faria-Rodrigues P. Mortars for old masonry renders - the influence of binders (in Portuguese) [PhD]. Lisbon: NOVA University of Lisbon, 2004. 
[47] Matias G, Faria-Rodrigues P, Torres I. Lime mortars with brick dust and grounded particles for ancient masonry: development and evaluation. In Historic Mortars Conference HMC2008, Lisbon, Portugal, 2008.

[48] Velosa A. Lime mortars with pozzolans for old masonry coating (in Portuguese) [PhD]. Aveiro, Portugal: Aveiro University, 2006.

[49] Moropoulou A, Bakolas A, Moundoulas P, Aggelakopoulou E. Reverse Engineering: A proper methodology for compatible restoration mortars. In RILEM Workshop Repair Mortars for Historic Masonry, Delft, 2005.

[50] Faria-Rodrigues P. Resistance to chlorides and sulfates of air lime mortars with different pozzolans (in Portuguese). In COMPASS Seminar - Soluble Salts in Mortars for Old Buildings - Damage, Processes and Solutions, Lisbon, 2005.

\section{Tables}

Table 1: Characteristics of the gathered ceramic products (information from the factories)

\begin{tabular}{|c|c|c|c|c|c|c|c|}
\hline Product & Factory & $\begin{array}{c}\text { Product } \\
\text { description }\end{array}$ & $\begin{array}{c}\text { Raw } \\
\text { materials }\end{array}$ & $\begin{array}{c}\text { Maximum } \\
\text { heating } \\
\text { temperature } \\
\left({ }^{\circ} \mathrm{C}\right)\end{array}$ & $\begin{array}{l}\text { Heating } \\
\text { period } \\
\text { (h) }\end{array}$ & $\begin{array}{l}\text { Amount } \\
\text { of waste } \\
\text { (ton/year) }\end{array}$ & $\begin{array}{l}\text { Waste } \\
\text { treatment }\end{array}$ \\
\hline W1 & A & $\begin{array}{l}\text { Common red } \\
\text { roof tile }\end{array}$ & $\begin{array}{l}\text { Lean clay } \\
\text { Fat clay } \\
\text { Silica } \\
\text { Sand }\end{array}$ & 920 & 73 & 740 & Landfill \\
\hline W2 & \multirow{8}{*}{ B } & $\begin{array}{l}\text { Common red } \\
\text { roof tile }\end{array}$ & $\begin{array}{l}\text { Lean clay } \\
\text { Fat clay } \\
\text { White sand }\end{array}$ & \multirow{8}{*}{1050} & \multirow{8}{*}{17} & 2000 & \multirow{8}{*}{ Landfill } \\
\hline W3 & & $\begin{array}{l}\text { "High quality } \\
\text { red" roof tile }\end{array}$ & $\begin{array}{l}\text { Lean clay } \\
\text { Fat clay } \\
\text { White sand }\end{array}$ & & & \multirow{4}{*}{4000} & \\
\hline \multirow{3}{*}{ W4 } & & $\begin{array}{l}\text { "High quality } \\
\text { glazed red" } \\
\text { roof tile }\end{array}$ & \multirow{3}{*}{$\begin{array}{l}\text { Lean clay } \\
\text { Fat clay } \\
\text { White sand } \\
\text { Pigments or } \\
\text { glazing }\end{array}$} & & & & \\
\hline & & $\begin{array}{l}\text { "High quality } \\
\text { glazed blue" } \\
\text { roof tile }\end{array}$ & & & & & \\
\hline & & $\begin{array}{l}\text { Brown roof } \\
\text { tile }\end{array}$ & & & & & \\
\hline \multirow{3}{*}{ W5 } & & $\begin{array}{l}\text { "High quality } \\
\text { white" roof } \\
\text { tile }\end{array}$ & \multirow{3}{*}{$\begin{array}{c}\text { Commercial } \\
\text { paste } \\
\text { (composition } \\
\text { not } \\
\text { available) }\end{array}$} & & & \multirow{3}{*}{$\begin{array}{c}\text { Not } \\
\text { available }\end{array}$} & \\
\hline & & $\begin{array}{l}\text { "High quality } \\
\text { glazed white" } \\
\text { roof tile }\end{array}$ & & & & & \\
\hline & & $\begin{array}{l}\text { "High quality } \\
\text { painted } \\
\text { white" roof }\end{array}$ & & & & & \\
\hline
\end{tabular}




\begin{tabular}{|c|c|c|c|c|c|c|c|}
\hline W6 & C & Brick & $\begin{array}{c}\text { Yellow clay } \\
(60-65 \%) \\
\text { Red Clay } \\
(30-35 \%) \\
\text { Sand (10\%) }\end{array}$ & 900 & $\begin{array}{c}\text { Not } \\
\text { available }\end{array}$ & 730 & Landfill \\
\hline W7 & D & Pottery & $\begin{array}{c}\text { Kaolinitic } \\
\text { clay }\end{array}$ & 1100 & $\begin{array}{c}\text { Not } \\
\text { available }\end{array}$ & 100 & $\begin{array}{c}\text { Waste pick } \\
\text { and } \\
\text { recycling } \\
\text { company }\end{array}$ \\
\hline
\end{tabular}

Table 2: Percentages of W4 and W5 mixed ceramic waste components

\begin{tabular}{|c|c|c|}
\hline Product & Component & Proportion (\%) \\
\hline \multirow{3}{*}{ W4 } & "High quality glazed red" tile & 50.0 \\
\hline & "High quality glazed blue" tile & 16.7 \\
\hline & Brown tile & 33.3 \\
\hline \multirow{3}{*}{ W5 } & "High quality white" tile & 33.3 \\
\hline & $\begin{array}{l}\text { "High quality glazed white" } \\
\text { tile }\end{array}$ & 33.3 \\
\hline & $\begin{array}{c}\text { "High quality painted white" } \\
\text { tile }\end{array}$ & 33.3 \\
\hline
\end{tabular}

Table 3: Los Angeles coefficient (LA) of the ceramic wastes

\begin{tabular}{|c|c|c|c|c|c|c|c|}
\hline Product & W1 & W2 & W3 & W4 & W5 & W6 & W7 \\
\hline LA (-) & 39 & 33 & 29 & 28 & 46 & 39 & 38 \\
\hline
\end{tabular}

Table 4: Physical properties of ceramic wastes (after milling), river sand and air lime

\begin{tabular}{|c|c|c|c|c|c|c|c|c|c|}
\hline Material & W1 & W2 & W3 & W4 & W5 & W6 & W7 & $\begin{array}{c}\text { River } \\
\text { sand }\end{array}$ & Air lime \\
\hline $\mathbf{F M}(-)$ & 2.06 & 2.29 & 2.54 & 2.83 & 1.76 & 2.41 & 2.17 & 3.42 & - \\
\hline$\rho_{\mathrm{a}}\left(\mathbf{g} / \mathbf{c m}^{3}\right)$ & 2.69 & 2.70 & 2.64 & 2.58 & 2.65 & 2.67 & 2.64 & 2.56 & - \\
\hline$\rho_{\text {rd }}\left(\mathbf{g} / \mathbf{c m}^{3}\right)$ & 2.06 & 2.27 & 2.32 & 2.27 & 2.27 & 1.95 & 2.15 & 2.55 & - \\
\hline$\rho_{\mathbf{s s d}}\left(\mathbf{g} / \mathbf{c m}^{\mathbf{3}}\right)$ & 2.29 & 2.43 & 2.44 & 2.39 & 2.41 & 2.22 & 2.34 & 2.55 & - \\
\hline $\mathbf{W A}_{\mathbf{2 4}}(\%)$ & 11.32 & 7.02 & 5.15 & 5.23 & 6.33 & 13.91 & 8.59 & 0.04 & - \\
\hline$\rho_{\mathrm{bi}}\left(\mathbf{g} / \mathbf{c m}^{3}\right)$ & 1.17 & 1.38 & 1.41 & 1.45 & 1.16 & 1.10 & 0.98 & 1.54 & 0.36 \\
\hline $\mathbf{v}(\%)$ & 43.1 & 39.3 & 39.2 & 36.4 & 48.6 & 43.6 & 54.0 & 39.7 & - \\
\hline
\end{tabular}

FM-Fineness Modulus; $\rho_{\mathbf{a}}$ - apparent particle density; $\rho_{\text {rd }}$ - particle density on an oven-dried basis; $\rho_{s s d}-$ particle density on a saturated and surface-dried basis; $W_{24}$ - water absorption after immersion for 24 hours; $\rho_{b i}$ - Loose bulk density; $v$ - percentage of voids. 
Table 5: Specific surface area (Sca) and percentages of each dimension (d) for ceramic dust and air lime - average and standard deviation

\begin{tabular}{|c|c|c|c|c|c|c|c|c|}
\hline \multirow{2}{*}{ Material } & \multicolumn{2}{|c|}{ Sca $\left(\mathbf{m}^{\mathbf{2}} \mathbf{g}\right)$} & \multicolumn{2}{c|}{$\mathbf{d}(\mathbf{0}, \mathbf{1}) \boldsymbol{\mu m}$} & \multicolumn{2}{c|}{$\mathbf{d}(\mathbf{0 , 5}) \boldsymbol{\mu m}$} & \multicolumn{2}{c|}{$\mathbf{d}(\mathbf{0 , 9}) \boldsymbol{\mu m}$} \\
\cline { 2 - 9 } & Average & StD & Average & $\mathbf{S t D}$ & Average & StD & Average & StD \\
\hline W1 & 1.1 & 0.02 & 2.0 & 0.06 & 19.6 & 0.61 & 55.7 & 0.81 \\
\hline W2 & 0.9 & 0.00 & 3.0 & 0.02 & 24.3 & 0.08 & 56.3 & 0.09 \\
\hline W3 & 1.1 & 0.01 & 2.1 & 0.03 & 15.5 & 0.22 & 47.6 & 0.52 \\
\hline W4 & 0.7 & 0.01 & 4.1 & 0.06 & 25.9 & 0.14 & 62.2 & 0.32 \\
\hline W5 & 0.9 & 0.00 & 2.7 & 0.00 & 22.6 & 0.02 & 54.9 & 0.17 \\
\hline W6 & 1.0 & 0.00 & 2.4 & 0.01 & 17.9 & 0.13 & 53.4 & 0.40 \\
\hline W7 & 1.1 & 0.00 & 2.3 & 0.00 & 14.5 & 0.04 & 44.8 & 0.28 \\
\hline Air Lime & 2.2 & 0.14 & 1.1 & 0.11 & 5.2 & 0.47 & 18.4 & 4.70 \\
\hline
\end{tabular}

Table 6: Qualitative mineral composition of ceramic waste

\begin{tabular}{|c|c|c|c|c|c|c|c|c|}
\hline \multicolumn{2}{|c|}{ Material } & \multirow{2}{*}{ W1 } & \multirow{2}{*}{ W2 } & \multirow{2}{*}{ W3 } & \multirow{2}{*}{ W4 } & \multirow{2}{*}{ W5 } & \multirow{2}{*}{ W6 } & \multirow{2}{*}{ W7 } \\
\hline & mpound & & & & & & & \\
\hline Quartz & $\mathrm{SiO}_{2}$ & $\checkmark$ & $\checkmark$ & $\checkmark$ & $\checkmark$ & $\checkmark$ & $\checkmark$ & $\checkmark$ \\
\hline Orthoclase & $\mathrm{KAISi}_{3} \mathrm{O}_{8}$ & $\checkmark$ & $\checkmark$ & $\checkmark$ & $\checkmark$ & $\checkmark$ & $\checkmark$ & $\checkmark$ \\
\hline Calcite & $\mathrm{CaCO}_{3}$ & $\checkmark$ & --- & --- & --- & $\mid---$ & $\checkmark$ & $\checkmark$ \\
\hline Hematite & $\mathrm{Fe}_{2} \mathrm{O}_{3}$ & $\checkmark$ & $\checkmark$ & $\checkmark$ & $\checkmark$ & $\checkmark$ & $\checkmark$ & --- \\
\hline Illite & $\left(\mathrm{K}_{2} \mathrm{H}_{3} \mathrm{O}\right) \mathrm{Al}_{2} \mathrm{Si}_{3} \mathrm{AlO}_{10}(\mathrm{OH})_{2}$ & $\checkmark$ & -- & -- & -- & --- & $\checkmark$ & $\checkmark$ \\
\hline Sillimanite/Mullite & $\mathrm{Al}_{6} \mathrm{Si}_{2} \mathrm{O}_{13}$ & --- & $\checkmark$ & $\checkmark$ & $\checkmark$ & $\checkmark$ & --- & --- \\
\hline
\end{tabular}

Table 7: Chemical composition (\% mass) and loss on ignition of air lime Lusical H100 [28]

\begin{tabular}{|c|c|c|c|c|c|c|c|c|c|}
\hline Material & $\mathrm{Al}_{2} \mathrm{O}_{3}$ & $\mathrm{Fe}_{2} \mathrm{O}_{3}$ & $\mathrm{MnO}$ & $\mathrm{MgO}$ & $\mathrm{CaO}$ & $\mathrm{K}_{2} \mathrm{O}$ & $\mathrm{TiO}_{2}$ & $\mathrm{P}_{2} \mathrm{O}_{5}$ & LOI. \\
\hline Air lime & 0.01 & 0.15 & 0.01 & 3.09 & 76.74 & 0.02 & 0.04 & 0.01 & 20.45 \\
\hline
\end{tabular}

Table 8: Ceramic wastes TGA and DTA results

\begin{tabular}{|c|c|c|c|c|c|c|c|}
\hline \multirow{3}{*}{ Material } & \multicolumn{4}{|c|}{ TGA } & \multicolumn{3}{|c|}{ DTA } \\
\hline & \multicolumn{2}{|c|}{$\begin{array}{c}\text { Weight loss - } \\
\text { Temperature }\left({ }^{\circ} \mathrm{C}\right)\end{array}$} & \multirow{2}{*}{$\begin{array}{l}\text { Weight } \\
\text { loss (\%) }\end{array}$} & \multirow{2}{*}{$\begin{array}{c}\text { Total } \\
\text { weight } \\
\text { loss (\%) }\end{array}$} & \multicolumn{2}{|c|}{ Temperature $\left({ }^{\circ} \mathrm{C}\right)$} & \multirow{2}{*}{$\begin{array}{l}\text { Type of } \\
\text { reaction }\end{array}$} \\
\hline & Start & End & & & $\begin{array}{l}\text { Reaction } \\
\text { start }\end{array}$ & $\begin{array}{l}\text { Inflection } \\
\text { point }\end{array}$ & \\
\hline \multirow{4}{*}{ W1 } & 20 & 47 & 0.1 & \multirow{4}{*}{0.9} & \multirow{2}{*}{21.5} & \multirow{2}{*}{98.2} & \multirow{2}{*}{ Endothermic } \\
\hline & 116 & 243 & 0.6 & & & & \\
\hline & 532 & 610 & 0.2 & & & & \\
\hline & 610 & 1000 & 0.1 & & $5 / 1.9$ & $0 / 3.5$ & Enaomermic \\
\hline \multirow{3}{*}{ W2 } & 20 & 69 & 0.1 & \multirow{3}{*}{0.7} & \multirow{2}{*}{25.8} & \multirow{2}{*}{89.4} & \multirow{2}{*}{ Endothermic } \\
\hline & 138 & 323 & 0.6 & & & & \\
\hline & 323 & 1000 & 0.1 & & 570.2 & 577.0 & Endothermic \\
\hline
\end{tabular}




\begin{tabular}{|c|c|c|c|c|c|c|c|}
\hline \multirow{2}{*}{ W3 } & 20 & 304 & 0.3 & \multirow{2}{*}{0.4} & 18.9 & 75.7 & Endothermic \\
\hline & 727 & 1000 & 0.1 & & 570.0 & 576.4 & Endothermic \\
\hline \multirow{2}{*}{ W4 } & 20 & 294 & 0.3 & \multirow{2}{*}{0.4} & 23.5 & 79.4 & Endothermic \\
\hline & 705 & 838 & 0.1 & & 568.5 & 575.9 & Endothermic \\
\hline \multirow{2}{*}{ W5 } & 20 & 49 & 0.1 & \multirow{2}{*}{1.1} & 20.5 & 96.3 & Endothermic \\
\hline & 111 & 235 & 0.9 & & 570.4 & 577.3 & Endothermic \\
\hline \multirow{3}{*}{ W6 } & 20 & 52 & 0.2 & \multirow{3}{*}{1.1} & 210 & $82 ?$ & Fndothermic \\
\hline & 111 & 244 & 0.6 & & 21.0 & UL.L & Licustrom \\
\hline & 716 & 795 & 0.2 & & 571.7 & 579.0 & Endothermic \\
\hline \multirow{4}{*}{ W7 } & 20 & 49 & 0.1 & \multirow{4}{*}{1.2} & \multirow{2}{*}{22.0} & \multirow{2}{*}{81.8} & \multirow{2}{*}{ Endothermic } \\
\hline & 103 & 208 & 0.7 & & & & \\
\hline & 360 & 483 & 0.2 & & \multirow{2}{*}{571.8} & \multirow{2}{*}{577.6} & \multirow{2}{*}{ Endothermi } \\
\hline & 483 & 1000 & 0.1 & & & & \\
\hline
\end{tabular}

Table 9: Fine and granular ceramic waste particles loose bulk density

\begin{tabular}{|c|c|c|c|c|c|c|}
\cline { 2 - 7 } \multicolumn{1}{c|}{} & \multicolumn{3}{c|}{ Material $<\mathbf{0 . 0 6 3} \mathbf{~ m m}$} & \multicolumn{3}{c|}{ Material $>\mathbf{0 , 0 6 3} \mathbf{~ m m}$} \\
\cline { 2 - 7 } \multicolumn{1}{c|}{} & $\mathbf{W} 1$ & $\mathbf{W 6}$ & $\mathbf{P} \mathbf{( W 7 )}$ & $\mathbf{W} 1$ & $\mathbf{W 6}$ & $\mathbf{W 7}$ \\
\hline$\rho_{\mathrm{bi}}\left(\mathbf{g} / \mathbf{c m}^{\mathbf{3}}\right)$ & 0.792 & 0.705 & 0.679 & 0.992 & 1.061 & 1.123 \\
\hline
\end{tabular}

Table 10: Volumetric and weight mortar compositions considering dust and granular ceramic particles

\begin{tabular}{|c|c|c|c|c|c|c|c|c|c|c|}
\hline \multirow{3}{*}{ Mortar } & \multicolumn{8}{|c|}{ Volumetric composition } & \multirow{3}{*}{$\begin{array}{l}\text { Weight comp. } \\
\text { [CL:D+G, G or } \\
\text { D:R sand] }\end{array}$} & \multirow{3}{*}{$\begin{array}{c}\text { Fine/grain } \\
\text { volumetric } \\
\text { ratio }\end{array}$} \\
\hline & \multirow{2}{*}{ CL } & \multicolumn{2}{|c|}{ W1 } & \multicolumn{2}{|c|}{ W6 } & \multicolumn{2}{|c|}{ W7 } & \multirow{2}{*}{$\begin{array}{l}\text { River } \\
\text { sand }\end{array}$} & & \\
\hline & & D & $\mathbf{G}$ & D & $\mathbf{G}$ & D & $\mathbf{G}$ & & & \\
\hline $\mathbf{R}$ & 1 & \multicolumn{2}{|c|}{ - } & \multicolumn{2}{|c|}{ - } & \multicolumn{2}{|c|}{ - } & 3 & $1: 12.8$ & 0.33 \\
\hline LB & 1 & \multicolumn{2}{|c|}{-} & \multicolumn{2}{|c|}{0.6} & \multicolumn{2}{|c|}{ - } & 2.4 & $1: 1.8: 10.2$ & 0.35 \\
\hline HB & 1 & \multicolumn{2}{|c|}{-} & \multicolumn{2}{|c|}{1.2} & \multicolumn{2}{|c|}{-} & 1.8 & $1: 3.6: 7.7$ & 0.37 \\
\hline LT & 1 & \multicolumn{2}{|c|}{0.6} & \multicolumn{2}{|c|}{ 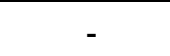 } & \multicolumn{2}{|c|}{-} & 2.4 & $1: 1.9: 10.2$ & 0.36 \\
\hline HT & 1 & \multicolumn{2}{|c|}{1.2} & \multicolumn{2}{|c|}{-} & \multicolumn{2}{|c|}{-} & 1.8 & $1: 3.9: 7.7$ & 0.38 \\
\hline LP & 1 & \multicolumn{2}{|c|}{-} & \multicolumn{2}{|c|}{-} & \multicolumn{2}{|c|}{0.6} & 2.4 & $1: 1.6: 10.2$ & 0.35 \\
\hline HP & 1 & \multicolumn{2}{|c|}{-} & \multicolumn{2}{|c|}{-} & \multicolumn{2}{|c|}{1.2} & 1.8 & 1:3.3:7.7 & 0.36 \\
\hline LGB & 1 & - & - & - & 0.6 & - & - & 2.4 & $1: 1.8: 10.2$ & 0.33 \\
\hline HGB & 1 & - & - & - & 1.2 & - & - & 1.8 & $1: 3.5: 7.7$ & 0.33 \\
\hline LGT & 1 & - & 0.6 & - & - & - & - & 2.4 & $1: 1.6: 10.2$ & 0.33 \\
\hline HGT & 1 & - & 1.2 & - & - & - & - & 1.8 & $1: 3.3: 7.7$ & 0.33 \\
\hline LGP & 1 & - & - & - & - & - & 0.6 & 2.4 & $1: 1.9: 10.2$ & 0.33 \\
\hline HGP & 1 & - & - & - & - & - & 1.2 & 1.8 & $1: 3.7: 7.7$ & 0.33 \\
\hline LDB & 1 & - & - & 0.11 & - & - & - & 3.33 & $1: 0.2: 14.2$ & 0.33 \\
\hline HDB & 1 & - & - & 0.25 & - & - & - & 3.75 & $1: 0.5: 16$ & 0.33 \\
\hline LDT & 1 & 0.11 & - & - & - & - & - & 3.33 & $1: 0.2: 14.2$ & 0.33 \\
\hline
\end{tabular}




\begin{tabular}{|c|c|c|c|c|c|c|c|c|c|c|} 
HDT & 1 & 0.25 & - & - & - & - & - & 3.75 & $1: 0.5: 16$ & 0.33 \\
\hline LDP & 1 & - & - & - & - & 0.11 & - & 3.33 & $1: 0.2: 14.2$ & 0.33 \\
\hline HDP & 1 & - & - & - & - & 0.25 & - & 3.75 & $1: 0.5: 16$ & 0.33 \\
\hline
\end{tabular}

Figures

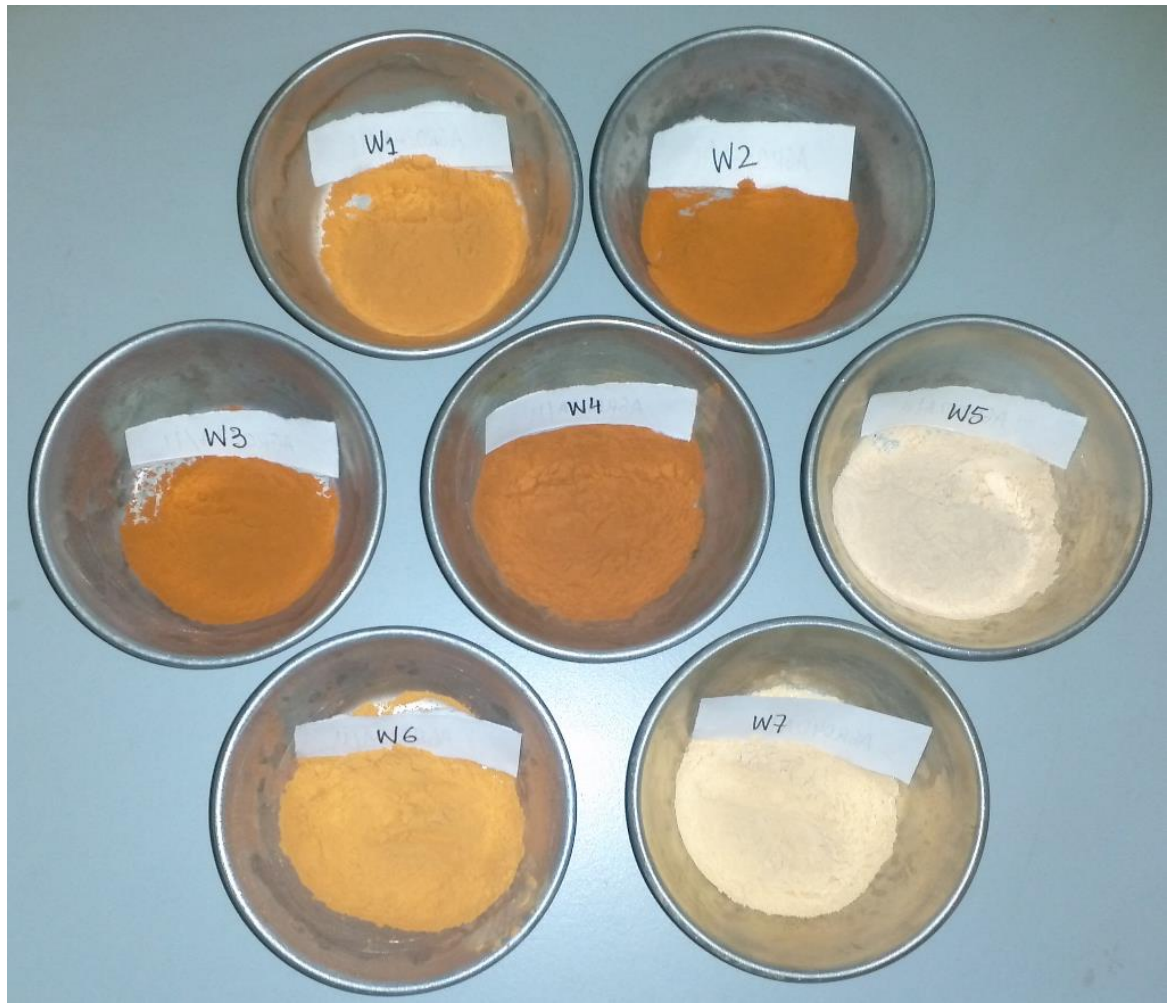

Figure 1: Dust fraction of ceramic wastes 


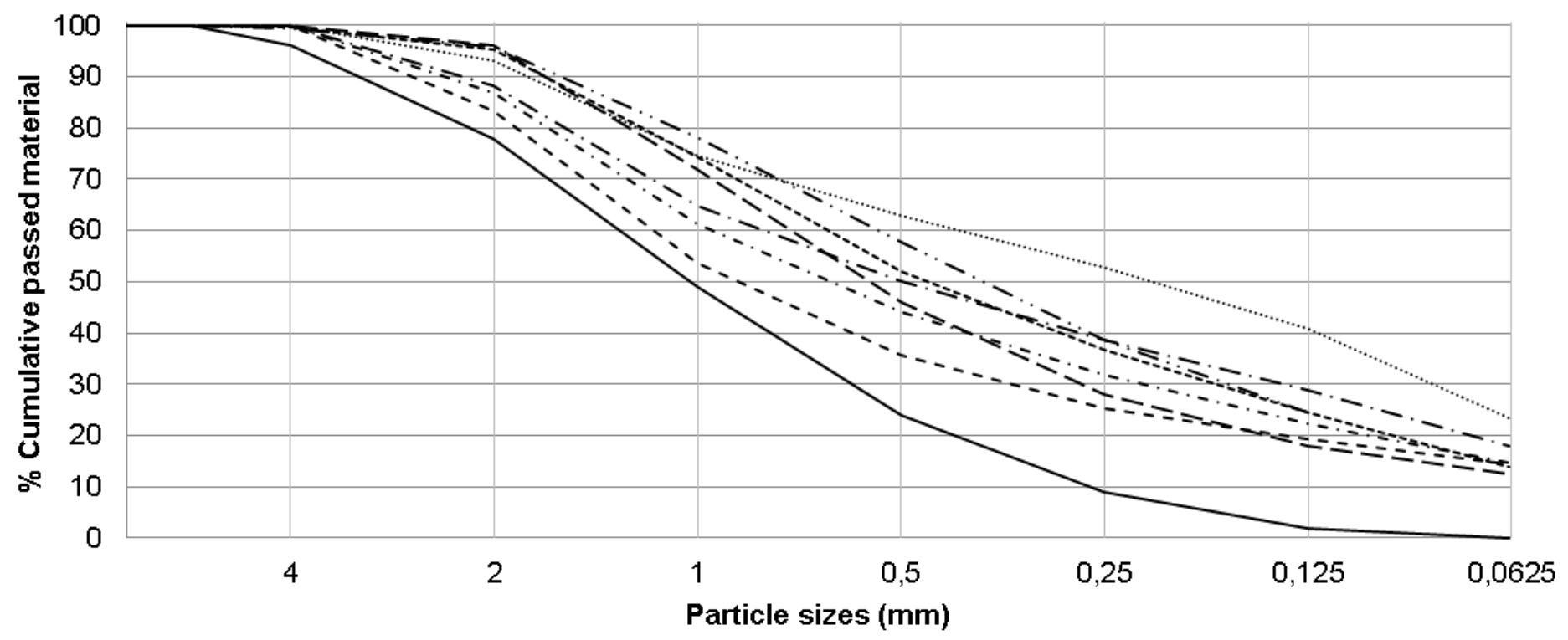

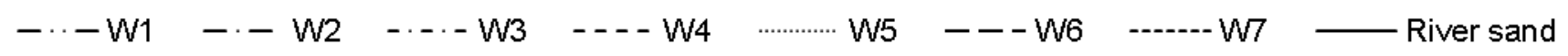

Figure 2: Particle size distribution of the ceramic wastes (after milling) and of river sand

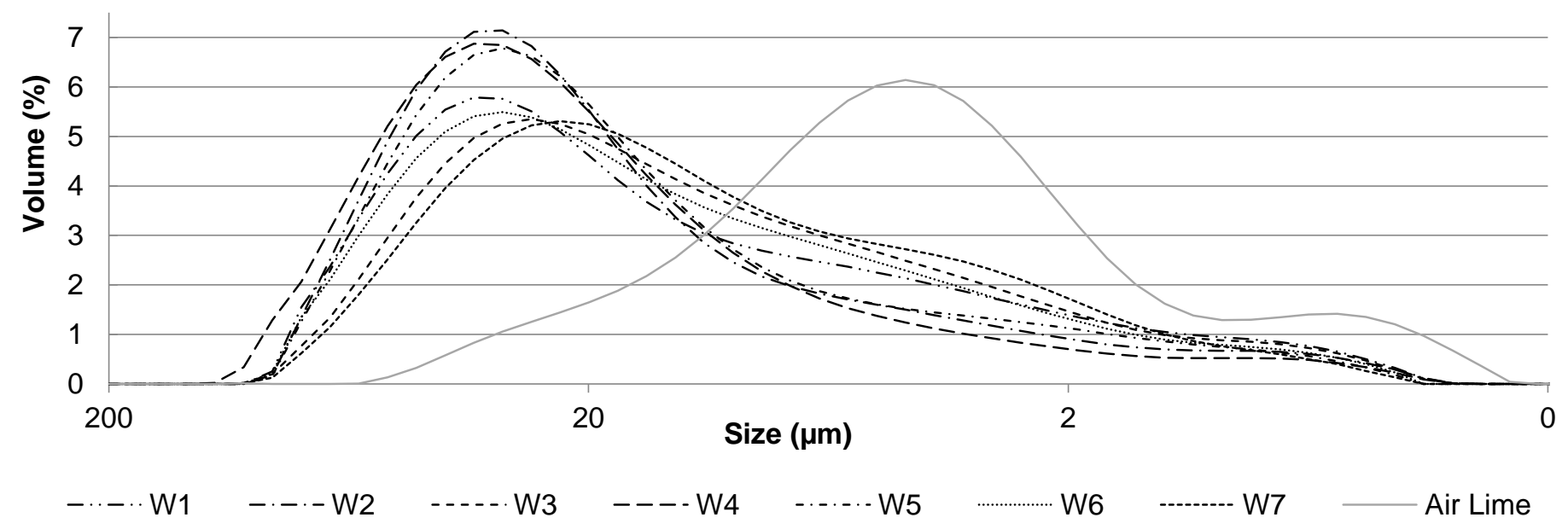

Figure 3: Fine particles size distribution, as percentage of volume, of the ceramic wastes and air lime 


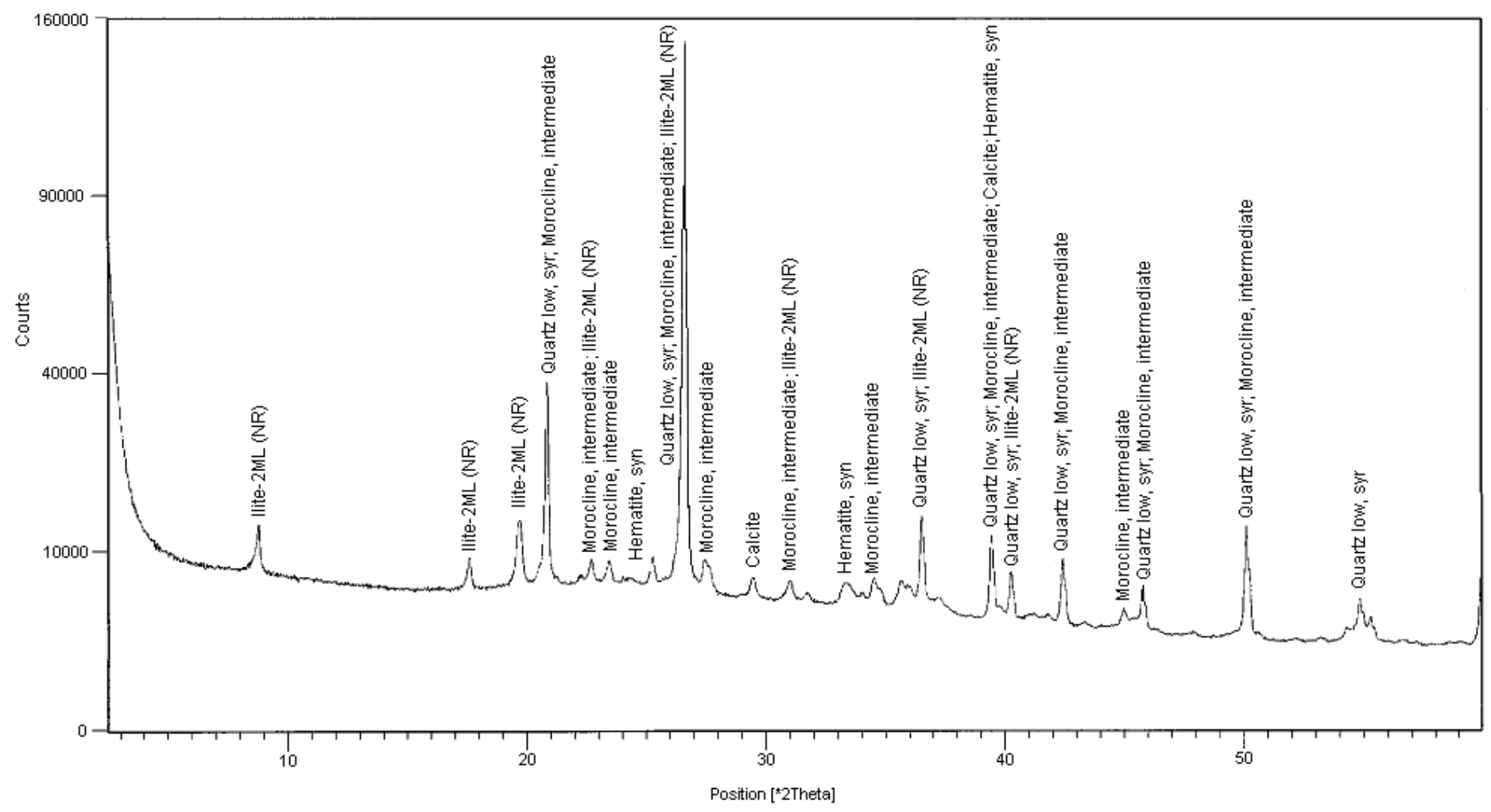

Figure 4: XRD difractogram of ceramic waste W6

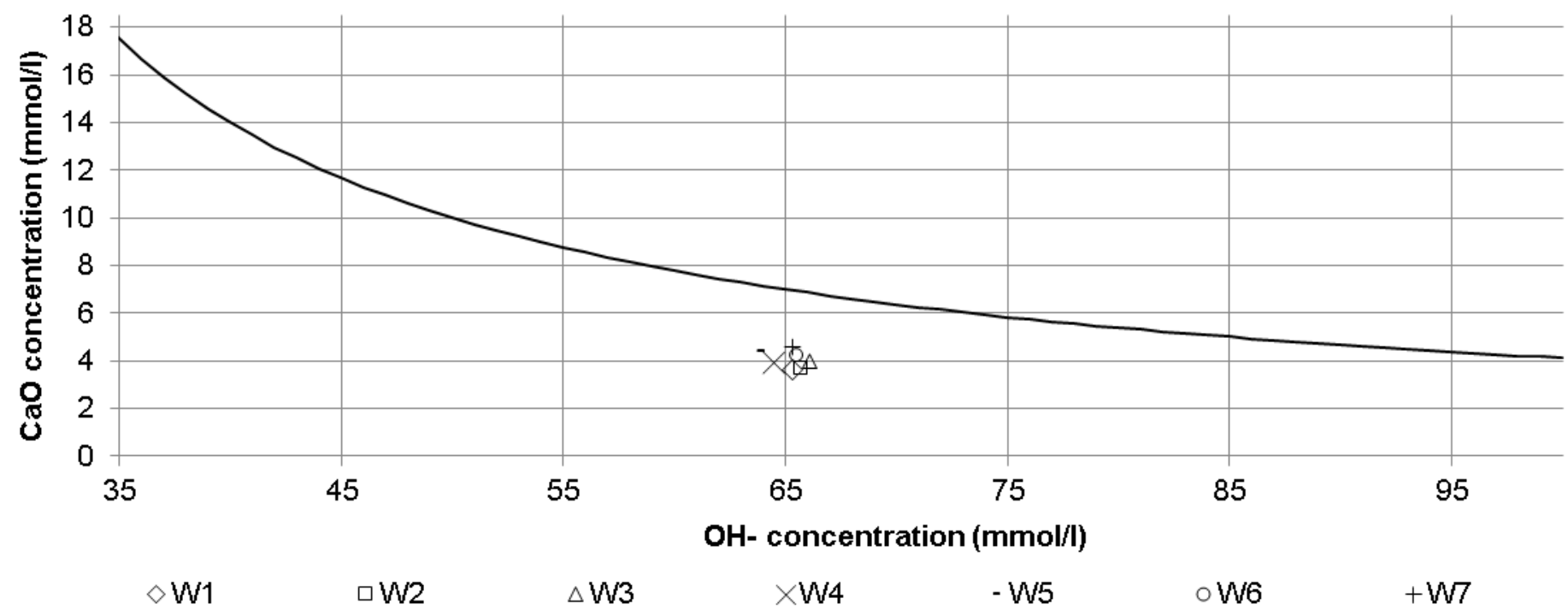

Figure 5: Pozzolanicity diagram of the ceramic wastes 


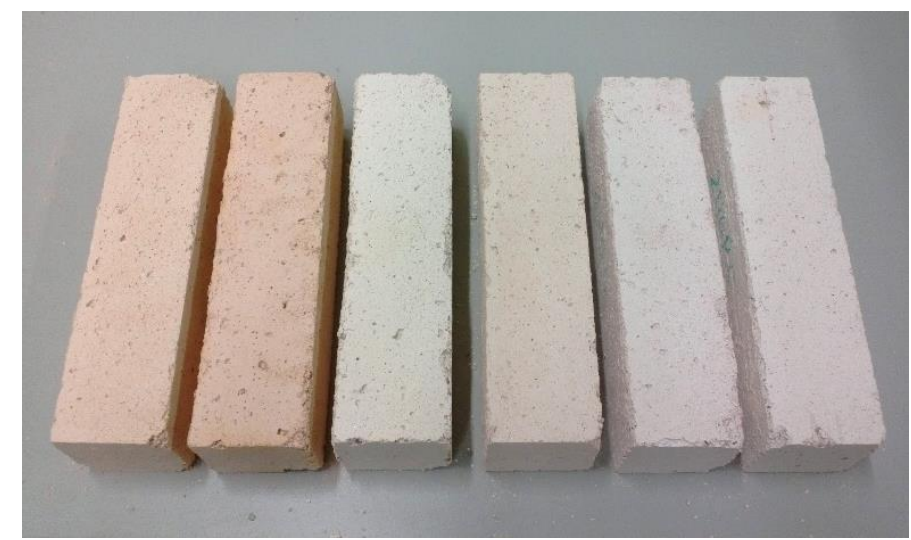

Figure 6: Prismatic specimens' examples and different colours

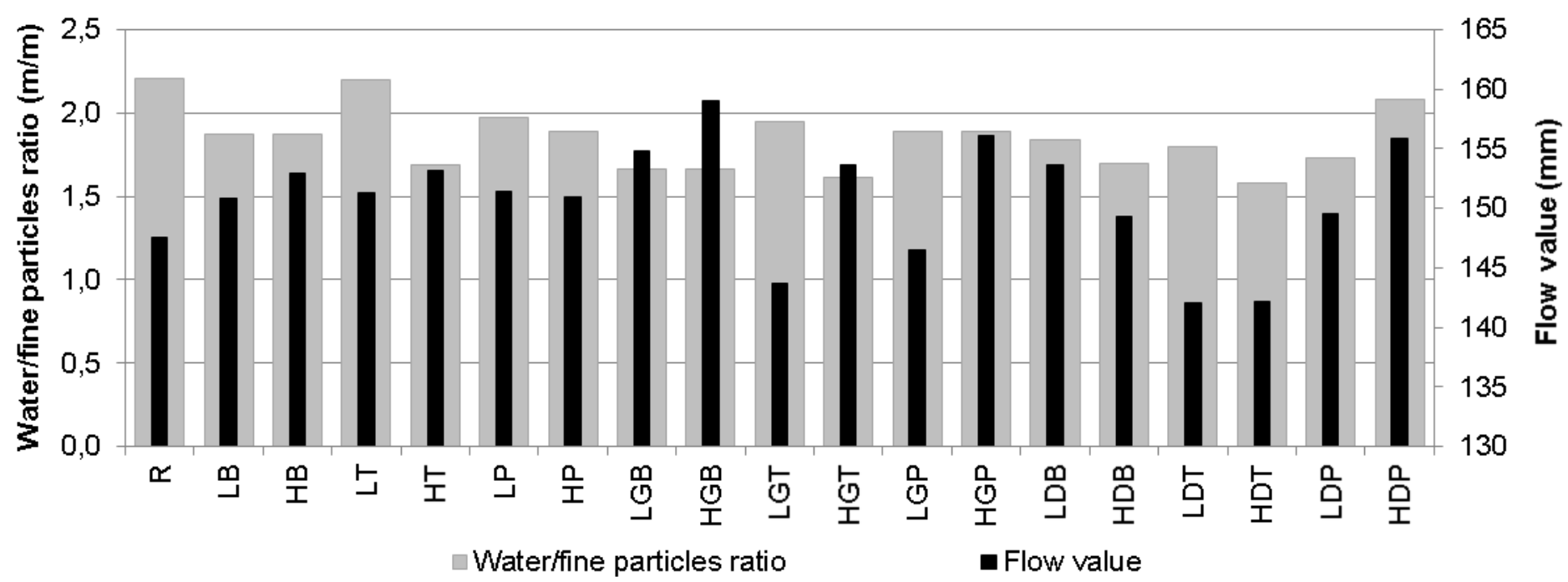

Figure 7: Flow table consistency and water/fine particles ratio of mortars

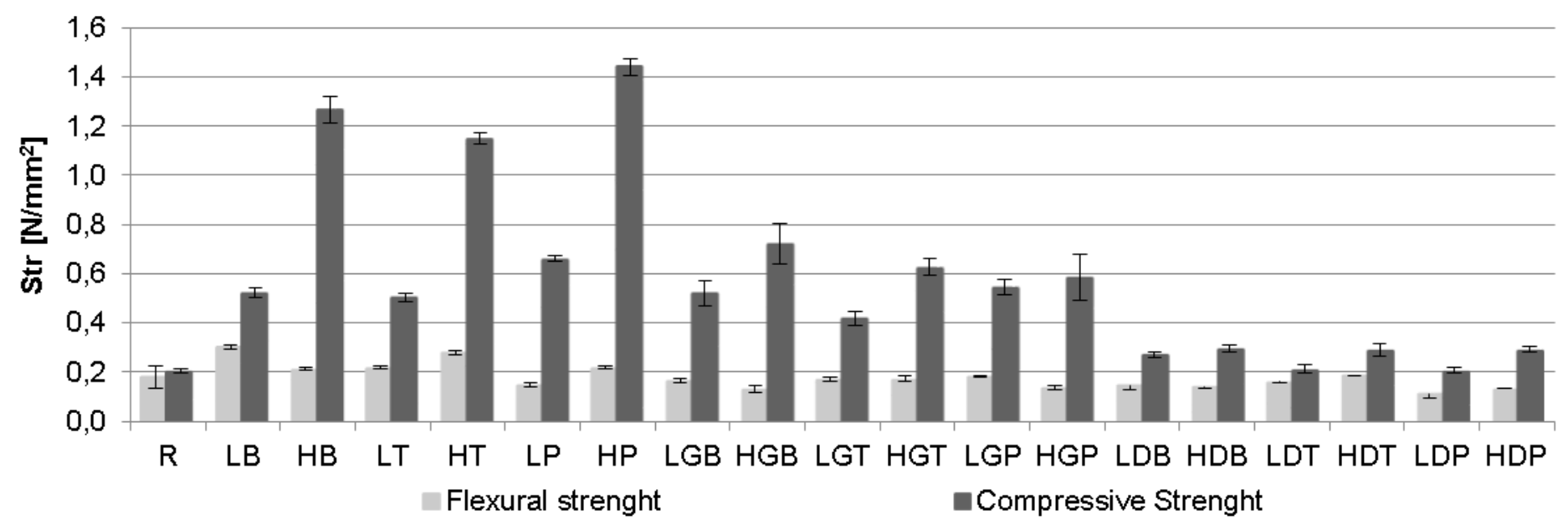

Figure 8: Flexural and compressive strength of mortars after 60 days of curing 


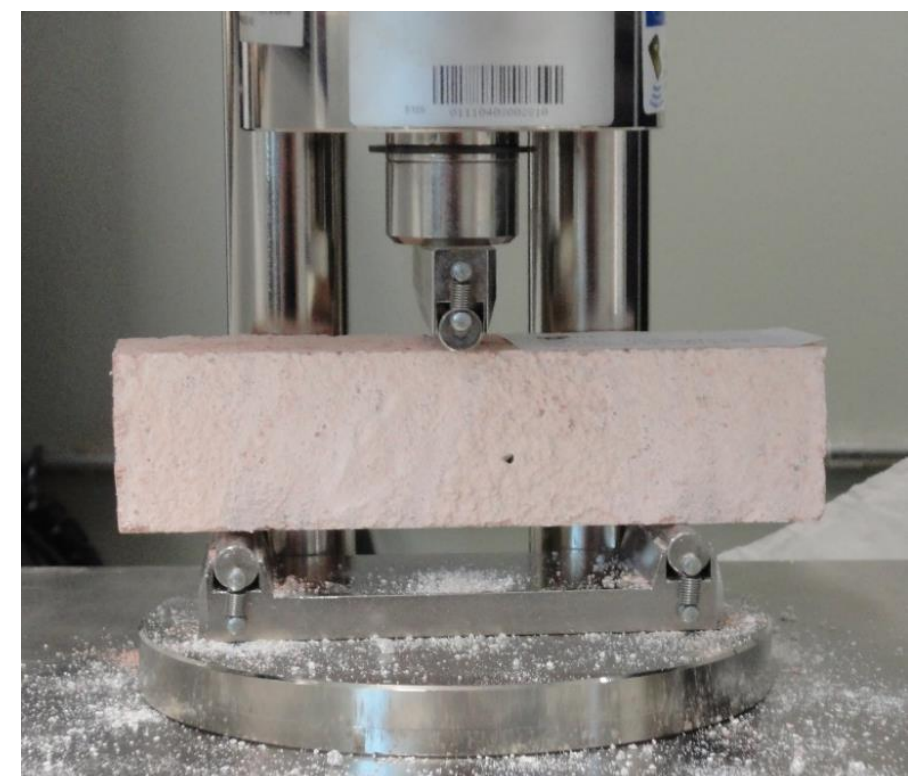

Figure 9: Flexural strength test device 